\title{
Evaluasi Ukuran dan Bentuk Biji Genotip-genotip Mutan Kedelai Generasi $\mathbf{M}_{4}$
}

\author{
Evaluation of Seed Size and Shape of $M_{4}$ Mutant Soybean \\ Genotypes
}

\author{
Elfan Waisimon ${ }^{1}$, Noladhi Wicaksana ${ }^{2}$, Anas $^{2}$, Meddy Rachmadi ${ }^{2}$ \\ ${ }^{1}$ Program Pascasarjana, Fakultas Pertanian, Universitas Padjadjaran \\ ${ }^{2}$ Fakultas Pertanian, Universitas Padjadjaran
}

\begin{abstract}
Soybean was one of the most important crop plants in Indonesia, but the need has not been fulfilled yet because its productivity was low. This study aims to obtain genotypes of M4 soybean mutant generation based on phenotypic characters of seed size and seed shape. The experiment was carried out in the experimental methods without spatial design, used 19 soybean mutant genotypes on M4 generation and Arjasari variety as a control. Eight characters of seed size (seed length, seed thickness, seed width, seed dimension, and 100 seed weight) and seed shape (seed length-thickness ratio, seed length-width ratio, and seed thickness-width ratio) have observed. Data analyzed with F-test, z-test, cluster analysis, and correlation analysis. The results showed that the seed size and seed shape characters had narrow intrapopulation variations. Eight genotypes of soybean mutants, namely MRAR 14-11-17-5, MRAR 15-17-31-11, MRAR 26-6-2 1-8, MRAR 29-12-26-11, MRAR 29-15-33 -7, MRAR 2915-36-4, MRAR 29-15-36-8, and MRAR 29-15-30-10, have more significant seed size characters compared to Arjasari varieties. The MRAR genotypes 15-17-31-11 and MRAR 29-12-27-8 have a more rounded seed shape than the Arjasari variety. The seed size and seed shape characters correlated very strongly with each other. Seed size characters do not associate with seed shape characters.
\end{abstract}

Keywords: Variation, Performance, Correlation, Linkage, Cluster Analysis

\begin{abstract}
Abstrak: Kedelai merupakan salah satu komoditas pangan utama di Indonesia, namun kebutuhannya masih belum karena produktivitasnya masih rendah. Penelitian ini bertujuan untuk memperoleh genotip-genotip mutan kedelai generasi M4 berdasarkan karakter fenotipik ukuran biji dan bentuk biji. Percobaan dilaksanakan di kebun percobaan Fakultas Pertanian Universitas Padjadjaran, Jatinangor, didasarkan metode eksperimental tanpa rancangan tata ruang, menggunakan 19 genotip mutan kedelai generasi M4 serta varietas Arjasari sebagai pembanding. Delapan karakter ukuran biji (panjang biji, tebal biji, lebar biji, dimensi biji, dan bobot 100 biji) serta karakter bentuk biji (rasio panjang-tebal biji, rasio panjang-lebar biji, dan rasio lebar-tebal biji) diamati. Data dianalisis menggunakan uji F, uji-z, analisis cluster, serta analisis korelasi sederhana. Hasil penelitian menunjukkan bahwa karakter-karakter ukuran biji dan bentuk biji memiliki variasi intrapopulasi sempit. Delapan genotip mutan kedelai, yaitu MRAR 14-11-17-5, MRAR 15-17-31-11, MRAR 26-6-21-8, MRAR 29-12-26-11, MRAR 29-15-33-7, MRAR 29-15-36-4, MRAR 29-15-36-8, dan MRAR 29-15-30-10, memiliki karakter-karakter ukuran biji yang lebih besar dibandingkan dengan varietas Arjasari. Genotip MRAR 15-17-31-11 dan MRAR 2912-27-8 memiliki bentuk biji lebih bulat berbeda dengan varietas Arjasari. Karakter-karakter ukuran biji dan bentuk biji masing-masing saling berkorelasi sangat kuat. Karakter-karakter ukuran biji tidak berkorelasi dengan karakter-karakter bentuk biji.
\end{abstract}

Kata kunci: Variasi, Penampilan, Korelasi, Linkage, Analisis Kluster

\section{Pendahuluan}

Kedelai merupakan tanaman pangan terpenting di Indonesia setelah padi dan jagung, dengan kandungan protein tinggi sekiat 40\% (Krisnawati, 2017).
Kebutuhan kedelai terus meningkat namun ketersediannya relatif terbatas, sehingga pemenuhannya dilakukan melalui impor yang volumenya terus meningkat. Peningkatan produksi kedelai harus dilakukan antara lain melalui 
perakitan varietas unggul baru berdaya hasil tinggi (Arsyad 2000).

Perakitan varietas unggul dalam pemuliaan tanaman dapat dilakukan melalui induksi mutasi. Teknik ini merupakan salah satu cara untuk meningkatkan variasi genetik tanaman. Pemuliaan tanaman melalui induksi mutasi telah dikembangkan secara luas pada berbagai komoditas dan efektif untuk tanaman autogamous dengan variasi genetik sempit (Mickle, 1988). Ukuran dan bentuk biji kedelai pada umumnya memiliki variasi genetik yang sempit. Karakter ukuran biji kedelai, yaitu panjang biji, lebar biji, dan tebal biji, berkaitan dengan karakter bobot biji kedelai (Liang et al., 2008). Karakter bentuk biji, yang merupakan rasio antar karakter-karakter ukuran biji, berkaitan dengan preferensi pasar (Krisdiana, 2004). Beberapa varietas unggul kedelai hasil mutasi memiliki ukuran biji besar dengan daya hasil tinggi (Balai Penelitian Tanaman Kacang-kacangan dan Ubiubian, 2018).

Evaluasi karakteristik fenotipik merupakan pendekatan metode yang murah dan mudah digunakan secara langsung. Salas et al. (2006) mengevaluasi karakter fenotipik ukuran biji kedelai generasi $\mathrm{F}_{7}$ untuk panjang biji (PB), lebar biji (LB), tebal biji (TB, dan volume biji. Hal tersebut juga dilakukan oleh Dargahi et al. (2015) pada populasi kedelai generasi $\mathrm{F}_{2: 3}$ hasil persilangan antara varietas MJo004-6 asal Thailand dengan varietas R 18500 asal Myanmar. Selain ukuran biji tersebut, Xie et al. (2014) dan Teng et al. (2017) juga mengukur rasio panjanglebar biji $(\mathrm{P} / \mathrm{L})$, rasio panjang-tebal biji $(\mathrm{P} / \mathrm{T})$, dan rasio lebar-tebal biji (L/T); yang merupakan karakter-karakter penyusun bentuk biji.

Saat ini Laboratorium Pemuliaan Tanaman, Fakultas Pertanian, Universitas Padjadjaran, memiliki 19 genotip mutan kedelai Generasi $\mathrm{M}_{4}$ potensial dengan ukuran biji besar. Genotip-genotip tersebut merupakan hasil seleksi berdasarkan ukuran biji pada generasi $\mathbf{M}_{3}$. Penelitian ini bertujuan untuk memperoleh genotip-genotip mutan kedelai generasi $\mathrm{M}_{4}$ berdasarkan karakter fenotipik ukuran biji dan bentuk biji.

\section{Bahan dan Metode}

Percobaan ini dilaksanakan pada bulan Maret Juni 2018 yang bertempat di Kebun Percobaan Ciparanje, Fakultas Pertaian Universitas Padjadjaran Jatinangor Kabupaten Sumedang, Jawa Barat.
Ketinggian tempat sekitar 754 meter di atas permukaan laut (dpl), dan mempunyai curah hujan tipe C (agak basah) berdasarkan klasifikasi Schmidt dan Ferguson, jenis tanah inceptisol.

Materi genetik yang digunakan dalam percobaan ini menggunakan 19 genotip mutan kedelai generasi $\mathrm{M}_{4}$ yang sebelumnya diperoleh dari hasil iradiasi sinar gamma varietas Arjasari pada level dosis 150 Gy. Genotip mutan yang digunakan adalah MRAR 14-1 117-5, MRAR 15-17-31-11, MRAR 13-13-19-3, MRAR 13-5-16-5, MRAR 13-5-20-13, MRAR 26-621-8, MRAR 17-10-3-6, MRAR 28-15-21-7, MRAR 29-12-26-11, MRAR 29-12-27-8, MRAR 29-15-28-4, MRAR 29-15-32-12, MRAR 29-15-33-14, MRAR 29-15-33-5, MRAR 29-15-33-7, MRAR 29-15-36-4, MRAR 29-15-36-8, MRAR 29-15-30-10, dan MRAR 30-1-39-9. Percobaan disusun menggunakan rancangan tanpa tata ruang dengan menanam masing-masing genotip mutan kedelai dalam satu barisan tanaman, dengan jarak tanam dalam barisan $20 \mathrm{~cm}$ dan jarak antar barisan $50 \mathrm{~cm}$.

Pemupukan dilakukan sekali pada awal penanaman, dengan dosis $103 \mathrm{~kg} / \mathrm{ha}$ Urea, $75 \mathrm{~kg} / \mathrm{ha}$ SP 36, dan $128 \mathrm{~kg} / \mathrm{ha} \mathrm{KCl}$. Pemeliharaan tanaman seperti penyiraman, penyiangan, serta pengendalian hama dan penyakit dilakukan sesuai keperluan. Pengamatan karakter fenotipik meliputi panjang biji $(\mathrm{mm})$, tebal biji $(\mathrm{mm})$, lebar biji $(\mathrm{mm})$, rasio panjanglebar biji $(\mathrm{mm})$, rasio panjang-tebal biji $(\mathrm{mm})$, rasio lebar-tebal biji $(\mathrm{mm})$, dimensi biji $\left(\mathrm{mm}^{3}\right)$ diperoleh dari panjang $\mathrm{x}$ tebal $\mathrm{x}$ lebar, dan bobot 100 biji $(\mathrm{g})$.

Analisis data dilakukan meliputi uji $\mathrm{F}$ dilanjutkan dengan perhitungan varians fenotipik intra galur. Kriteria penilaian luas, sedang dan sempitnya koefisien varian dengan mengikuti (Qosim et al., 2000), yaitu : nilai KV Sempit (S) (0 - 24.94), Agak Sempit (AS) (24.94 - 49.71), dan Agak Luas (AL) (49.71 - 74.71), Luas (L) (74.71 - 99.65), Sangat Luas (SL) $(96.65<\mathrm{X})$. Untuk membandingkan penampilan dua populasi tanaman, dilakukan uji $\mathrm{Z}$ pada taraf 5\%. Selanjutnya, variasi fenotipik juga dianalisis melalui dendrogram menggunakan software NTSys 2.1.

\section{Hasil dan Pembahasan}

Salah satu kendala penerapan seleksi pada populasi generasi awal hasil mutasi adalah masih dijumpainya segregasi. Hal tersebut ditandai dengan variasi intrapopulasi yang relatif luas dari karakter yang diamati sehingga menyebabkan diperolehnya 
Tabel 1. Koefisien Varians Intrapopulasi Karakter-karakter Ukuran Biji pada Genotip-genotip Mutan Kedelai Generasi M 4

\begin{tabular}{|c|c|c|c|c|c|c|c|c|c|}
\hline \multirow{2}{*}{ No. } & \multirow{2}{*}{ Genotip } & \multicolumn{8}{|c|}{ Nilai KV (\%) ${ }^{1)}$} \\
\hline & & PB ${ }^{2)}$ & TB & LB & DB & B-100 & $\mathbf{P} / \mathbf{T}$ & $\mathrm{P} / \mathrm{L}$ & $\mathrm{L} / \mathrm{T}$ \\
\hline 1 & MRAR 14-11-17-5 & $5,32(\mathrm{~S})$ & $4,67(\mathrm{~S})$ & $5,08(\mathrm{~S})$ & $11,47 \quad(\mathrm{~S})$ & $7,98 \quad \mathrm{~S})$ & $5.24(\mathrm{~S})$ & $6,49(\mathrm{~S})$ & $5,47(\mathrm{~S})$ \\
\hline 2 & MRAR 15-17-31-11 & $8,60(\mathrm{~S})$ & $5,09(\mathrm{~S})$ & $5,47(\mathrm{~S})$ & $14,38 \quad(\mathrm{~S})$ & $6,35(\mathrm{~S})$ & $8.23(\mathrm{~S})$ & $9,36(\mathrm{~S})$ & $5,11(\mathrm{~S})$ \\
\hline 3 & MRAR 13-13-19-3 & $11,28(\mathrm{~S})$ & $9,00(\mathrm{~S})$ & $9,73(\mathrm{~S})$ & $25,80(\mathrm{AS})$ & $22,84(\mathrm{~S})$ & $8.37(\mathrm{~S})$ & $12,34(\mathrm{~S})$ & $7,97(\mathrm{~S})$ \\
\hline 4 & MRAR 13-5-16-5 & $10,84(\mathrm{~S})$ & $8,14(\mathrm{~S})$ & $8,44(\mathrm{~S})$ & $24,15 \quad(\mathrm{~S})$ & 24,96(AS) & $6.90(\mathrm{~S})$ & $9,01(\mathrm{~S})$ & $4,89(\mathrm{~S})$ \\
\hline 5 & MRAR 13-5-20-13 & $10,14(\mathrm{~S})$ & $7,40(\mathrm{~S})$ & $8,46(\mathrm{~S})$ & $22,90 \quad(\mathrm{~S})$ & 28,66(AS) & $8.93(\mathrm{~S})$ & $9,02(\mathrm{~S})$ & $7,57(\mathrm{~S})$ \\
\hline 6 & MRAR 26-6-2 1-8 & $6,68(\mathrm{~S})$ & 7,09 (S) & $9,30(\mathrm{~S})$ & $19,97 \quad(\mathrm{~S})$ & $12,67(\mathrm{~S})$ & $5.47(\mathrm{~S})$ & $7,40(\mathrm{~S})$ & $5,15(\mathrm{~S})$ \\
\hline 7 & MRAR 17-10-3-6 & $7,31(\mathrm{~S})$ & $8,04(\mathrm{~S})$ & $9,04(\mathrm{~S})$ & $20,91 \quad(\mathrm{~S})$ & $16,21(\mathrm{~S})$ & $7.71(\mathrm{~S})$ & $7,93(\mathrm{~S})$ & $4,81(\mathrm{~S})$ \\
\hline 8 & MRAR 28-15-21-7 & $9,43(\mathrm{~S})$ & $8,92(\mathrm{~S})$ & $11,57(\mathrm{~S})$ & 25,32(AS) & $26,21(\mathrm{AS})$ & $7.08(\mathrm{~S})$ & $10,57(\mathrm{~S})$ & $8,36(\mathrm{~S})$ \\
\hline 9 & MRAR 29-12-26-1 1 & $5,95(\mathrm{~S})$ & $5,33(\mathrm{~S})$ & $5,12(\mathrm{~S})$ & $13,49 \quad(\mathrm{~S})$ & $10,75(\mathrm{~S})$ & $5.47(\mathrm{~S})$ & $6,22(\mathrm{~S})$ & $3,74(\mathrm{~S})$ \\
\hline 10 & MRAR 29-12-27-8 & $6,26(\mathrm{~S})$ & $5,41(\mathrm{~S})$ & $6,96(\mathrm{~S})$ & $15,75 \quad(\mathrm{~S})$ & $13,19(\mathrm{~S})$ & $5.74(\mathrm{~S})$ & $6,74(\mathrm{~S})$ & $4,85(\mathrm{~S})$ \\
\hline 11 & MRAR 29-15-28-4 & $7,74(\mathrm{~S})$ & $6,23(\mathrm{~S})$ & $8,60(\mathrm{~S})$ & $19,70 \quad(\mathrm{~S})$ & $17,01(\mathrm{~S})$ & $5.48(\mathrm{~S})$ & $7,55(\mathrm{~S})$ & $4,85(\mathrm{~S})$ \\
\hline 12 & MRAR 29-15-32-12 & $11,99(\mathrm{~S})$ & $8,43(\mathrm{~S})$ & $9,05(\mathrm{~S})$ & $27,6(\mathrm{~A} \mathrm{~S})$ & $24,56(\mathrm{~S})$ & $7.07(\mathrm{~S})$ & $9,34(\mathrm{~S})$ & $5,39(\mathrm{~S})$ \\
\hline 13 & MRAR 29-15-33-14 & $9,23(\mathrm{~S})$ & $7,49(\mathrm{~S})$ & $10,20(\mathrm{~S})$ & $22,50(\mathrm{~S})$ & $18,53(\mathrm{~S})$ & $7.65(\mathrm{~S})$ & $12,13(\mathrm{~S})$ & $7,17(\mathrm{~S})$ \\
\hline 14 & MRAR 29-15-33-5 & $11,30(\mathrm{~S})$ & $8,40(\mathrm{~S})$ & $9,13(\mathrm{~S})$ & $24,97(\mathrm{~S})$ & $18,96(\mathrm{~S})$ & $8.31(\mathrm{~S})$ & $11,04(\mathrm{~S})$ & $5,90(\mathrm{~S})$ \\
\hline 15 & MRAR 29-15-33-7 & $9,56(\mathrm{~S})$ & $7,51(\mathrm{~S})$ & $7,99(\mathrm{~S})$ & $20,96(\mathrm{~S})$ & $17,44(\mathrm{~S})$ & $7.50(\mathrm{~S})$ & $10,42(\mathrm{~S})$ & $5,71(\mathrm{~S})$ \\
\hline 16 & MRAR 29-15-36-4 & $8,53(\mathrm{~S})$ & $5,42(\mathrm{~S})$ & $6,78(\mathrm{~S})$ & $18,42(\mathrm{~S})$ & $14,25(\mathrm{~S})$ & $5.46(\mathrm{~S})$ & $7,04(\mathrm{~S})$ & $4,41(\mathrm{~S})$ \\
\hline 17 & MRAR 29-15-36-8 & $8,39(\mathrm{~S})$ & $5,19(\mathrm{~S})$ & $6,80(\mathrm{~S})$ & $16,05(\mathrm{~S})$ & $11,91(\mathrm{~S})$ & $6.50(\mathrm{~S})$ & $9,88(\mathrm{~S})$ & $6,54(\mathrm{~S})$ \\
\hline 18 & MRAR 29-15-30-10 & $14,28(\mathrm{~S})$ & $8,78(\mathrm{~S})$ & $10,41(\mathrm{~S})$ & $21,58(\mathrm{~S})$ & $12,12(\mathrm{~S})$ & $6.21(\mathrm{~S})$ & $9,36(\mathrm{~S})$ & $5,23(\mathrm{~S})$ \\
\hline 19 & MRAR 30-1-39-9 & $15,21(\mathrm{~S})$ & $11,52(\mathrm{~S})$ & $11,72(\mathrm{~S})$ & $26,87(\mathrm{AS})$ & $10,40(\mathrm{~S})$ & $5.62(\mathrm{~S})$ & $7,96(\mathrm{~S})$ & $4,96(\mathrm{~S})$ \\
\hline
\end{tabular}

Keterangan: 1) Nilai KV Sempit $(\mathrm{S})=0-24.94 \%$, Agak Sempit (AS) = 24.94 - 49.71\%, Agak Luas (AL) $=49.71-74.71 \%$, Luas $(\mathrm{L})=74.71-99.65 \%$, dan Sangat Luas $(\mathrm{SL})=96.65-100 \%$ berdasarkan klasifikasi kriteria nilai relatif Qosim (2000);

2) $\mathrm{PB}=$ Panjang Biji; TB = Tebal Biji; LB = Lebar Biji; DB = Dimensi Biji; B-10O = Bobot 100 Biji; P $/ \mathrm{T}=$ Rasio Panjang-Tebal Biji, P/L = Rasio Panjang-Tebal Biji, dan L/T = Rasio Lebar-Tebal Biji.

nilai duga heritabilitas yang relatif kecil (Fehr, 1987). Untuk mengetahui besaran dan tingkat keluasan variasi dilakukan analisis varians intrapopulasi. Berdasarkan Tabel 1, variasi ukuran biji dari masingmasing 19 genotip mutan kedelai generasi $\mathbf{M}_{4}$ pada umumnya sempit; kecuali untuk karakter dimensi biji dan bobot 100 biji pada beberapa genotip kedelai $\mathbf{M}_{4}$ yang menunjukkan agak variasi agak sempit. Karakter-karakter ukuran biji yang memiliki variasi intrapopulasi sempit tersebut adalah, panjang biji (KV 5,32-15,21\%), tebal biji (KV 4,67-11,52\%), dan lebar biji (KV 5,08-11,72\%). Karakter-karakter ukuran biji lainnya, yaitu dimensi biji $(11,47-27,60 \%)$ dan bobot 100 biji (KV 6,35-28,66\%), dikategorikan bervariasi sempit dan agak sempit. Semua karakter bentuk biji, yaitu rasio panjang-tebal biji (KV 5,24-8,93\%), rasio panjang biji-lebar biji (KV 6,22 - 12,34\%), rasio tebal biji-lebar biji (KV 3,74 - 7,97\%), masing-masing dikategorikan bervariasi sempit. Hal tersebut mengindikasikan bahwa karakter ukuran biji dan bentuk biji pada genotip mutan kedelai $\mathrm{M}_{4}$ umumnya telah homosigot.

Menurut Allard (1961), pada populasi tanaman menyerbuk sendiri, efek segregasi setelah generasi keempat pada karakter yang dikendalikan oleh satu gen akan memberikan homosigositas sebesar $87,50 \%$. Nilai homosigositas akan menjadi lebih besar apabila pada generasi-generasi sebelumnya telah dilakukan seleksi yang terarah. Materi genetik pada penelitian merupakan hasil seleksi berdasarkan ukuran biji pada generasi $\mathbf{M}_{3}$. Selanjutnya, diduga segregasi pada karakter-karakter ukuran biji dan bentuk biji tersebut terjadi hanya pada satu gen tunggal. Menurut Acquuah (2007), efek mutasi dapat terjadi pada lingkup gen, kromosom, dan genom. 
Karakter dimensi biji tersusun atas dua komponen karakter diantara karakter panjang biji, tebal biji, dan lebar biji. Berdasarkan Tabel 1, pada karakter dimensi biji tercatat empat genotip kedelai $\mathrm{M}_{4}$ yaitu MRAR 13-13-19-3 (KV = 25,80\%), MRAR 28-15-21-7 (KV = 25,32\%), MRAR 29-15-32-12 (KV $=27,60 \%)$, dan MRAR 30-1-39-9 $(\mathrm{KV}=26,87 \%)$ memiliki variasi intrapopulasi yang dikategorikan agak sempit; selebihnya dikategorikan sempit. Diduga mutasi pada keempat genotip kedelai $\mathrm{M}_{4}$ tersebut terjadi pada lebih dari satu gen yang mengendalikan karakter dimensi biji. Hal tersebut serupa untuk karakter bobot 100 biji untuk genotip-genotip kedelai M4 MRAR 13-5-16-5 $(\mathrm{KV}=24,96 \%)$, MRAR $13-5-20-5(\mathrm{KV}=28,66 \%)$, dan MRAR 28-15-21-7 (KV = 26,21\%).

Dugaan kendali gen pada penelitian ini berbeda dengan hasil yang diperoleh dari beberapa peneliti sebelumnya. Beberapa peneliti melaporkan bahwa ukuran biji merupakan karakter yang bersifat Quantitative Traits Loci (QTL). Menurut Teng et al. (2017), karakter panjang biji dan lebar biji dikendalikan oleh lima gen. Selanjutnya karakter tebal biji dan rasio lebar biji-tebal biji dikendalikan oleh tiga gen. Lalu, karakter rasio panjang biji-lebar biji dan rasio panjang biji-tebal biji masing-masing dikendalikan oleh empat dan dua gen. Berbeda menurut Dargahi et al. (2015), yang melaporkan bahwa karakter panjang biji, lebar biji, dan tebal biji masing-masing dikendalikan oleh enam, tiga, dan empat gen.

Knight (1979) menyatakan bahwa variasi intrapopulasi sempit yang mengarah pada homosigositas mengindikasikan bahwa faktor genetik lebih berperan dalam mengendalikan suatu karakter dibandingkan dengan faktor lingkungan terhadap variabilitas total. Oleh karena itu, seleksi galur-galur kedelai tersebut diharapkan telah dapat dilakukan pada generasi berikutnya. Hal tersebut sejalan dengan pendapat Chahal dan Gosal (2006) galur homozigot umumnya sudah dapat diperoleh pada generasi M5.

Penerapan seleksi suatu karakter bermakna apabila pada genotip-genotip yang diuji terdapat penampilan yang unggul. Tabel 2 memperlihatkan hasil uji-z penampilan ukuran biji dan bentuk biji genotip-genotip mutan kedelai M4 dibandingkan dengan varietas Arjasari. Pembanding varietas Arjasari digunakan karena genotip-genotip kedelai mutan tersebut berasal dari varietas Arjasari yang diinduksi mutasi sinar gamma $150 \mathrm{~Gy}$.

Hasil uji-z (Tabel 2) menunjukkan bahwa induksi mutasi sinar gamma 150 Gy memberikan pengaruh yang berbeda-beda terhadap ukuran biji dan bentuk biji dari setiap genotip mutan kedelai M4. Hal tersebut menunjukkan bahwa pengaruh induksi mutasi bersifat acak. Menurut Hanafiah et al. (2010), mutan kedelai hasil iradiasi sinar gamma 150 Gy pada varietas Anjasmoro memiliki penurunan nilai pada empat dari enam karakter komponen hasil yang diuji. Bahkan, kedelai hasil iradiasi sinar gamma dapat menjadi steril atau mengalami penurunan jumlah mitokondria akibat kerusakan pada kromosomnya (Khan dan Tyagi, 2013). Namun Menurut Crowder (1986), induksi mutasi merupakan sumber utama pembentukan gen baru yang akan menimbulkan variasi genetik, sehingga dapat diperoleh karakteristik yang baru.

Induksi mutasi yang bersifat acak pada dasarnya akan membuka peluang diperolehnya karakteristik genetik unggul. Berdasarkan Tabel 2, sejumlah delapan genotip mutan kedelai generasi M4 memperlihatkan karakter-karakter ukuran biji yang lebih besar dibandingkan dengan varietas Arjasari; yaitu MRAR 14-11-17-5, MRAR 15-17-31-11, MRAR 26-6-21-8, MRAR 29-12-26-11, MRAR 2915-33-7, MRAR 29-15-36-4, MRAR 29-15-36-8, dan MRAR 29-15-30-10. Genotip-genotip mutan tersebut memiliki karakter panjang biji, tebal biji, lebar biji, dimensi biji, dan bobot 100 biji yang lebih besar dibandingkan dengan varietas Arjasari. Genotipgenotip mutan tersebut berpotensi memiliki daya hasil yang tinggi. Menurut Sihombing et al. (2016), kedelai hasil iradiasi sinar gamma dengan dosis $100-200 \mathrm{~Gy}$ dapat menghasilkan jumlah biji per tanaman dan bobot 100 biji genotip-genotip kedelai M3 yang berbeda nyata dibandingkan varietas Anjasmoro.

Ukuran biji dan bentuk biji merupakan karakteristik penting bagi pengguna bahan baku kedelai. Menurut Krisdiana (2004), produsen tempe di Jawa Timur lebih menginginkan biji kedelai berukuran besar dan berbentuk bulat. Menurutnya, ukuran besar dan bentuk bulat akan meningkatkan efisiensi penggunaan biji kedelai sebagai bahan baku tempe. Pada penelitian ini, tidak ada satu pun genotip mutan kedelai yang memiliki biji dengan bentuk bulat atau mendekati bulat. Parameter bentuk bulat apabila rasio panjang-tebal biji, rasio panjang-lebar biji, dan rasio tebal-lebar biji memiliki nilai 1,0 atau mendekat 1,o. Namun demikian, dari sejumlah 19 genotip mutan yang diuji, terdapat dua genotip mutan M4 yang memiliki bentuk lebih bulat dibandingkan varietas Arjasari, yaitu MRAR 15-17-31-11 dan MRAR 29-1227-8 (Tabel 2). Kedua genotip mutan tersebut memiliki rasio panjang-tebal biji, rasio panjang-lebar biji, dan rasio tebal-lebar biji yang lebih baik dibandingkan varietas Arjasari. Genotip mutan 
Tabel 2. Penampilan Karakter-karakter Ukuran Biji pada Genotip-genotip Mutan Kedelai Generasi $\mathbf{M}_{4}$

\begin{tabular}{|c|c|c|c|c|c|c|c|c|c|}
\hline No & Genotip & $\mathbf{P B}(\mathbf{m m})^{1)}$ & $\mathrm{TB}(\mathrm{mm})$ & $\mathbf{L B}(\mathbf{m m})$ & $\mathrm{DB}\left(\mathbf{m m}^{3}\right)$ & $\mathrm{B}-100(\mathrm{~g})$ & $\mathbf{P} / \mathbf{T}$ & $\mathbf{P} / \mathbf{L}$ & $\mathrm{T} / \mathrm{L}$ \\
\hline 1 & MRAR 14-11-17-5 & $8,31 \mathrm{a}^{2)}$ & $6,72 \mathrm{a}$ & 5,33 a & $298,91 \mathrm{a}$ & 16,40 a & 1,24 & 1,56 & 1,26 \\
\hline 2 & MRAR 15-17-31-11 & $7,97 \mathrm{a}$ & $6,57 \mathrm{a}$ & 5,25 a & $276,07 \mathrm{a}$ & $15,76 \mathrm{a}$ & $1,21 \mathrm{~b}$ & $1,52 \mathrm{~b}$ & $1,25 \mathrm{~b}$ \\
\hline 3 & MRAR 13-13-19-3 & 7,93 a & 6,11 & 4,86 & 239,74 & 13,12 & 1,30 & 1,64 & 1,26 \\
\hline 4 & MRAR 13-5-16-5 & 8,23 a & $6,35 \mathrm{a}$ & 4,94 & 263,09 a & $14,88 \mathrm{a}$ & 1,30 & 1,67 & 1,29 \\
\hline 5 & MRAR 13-5-20-13 & 7,64 & 6,00 & 4,67 & 222,58 & 10,68 & 1,27 & 1,63 & 1,29 \\
\hline 6 & MRAR 26-6-2 1-8 & $8,35 \mathrm{a}$ & 6,79 a & 5,36 a & 307,31 a & $16,60 \mathrm{a}$ & 1,23 & 1,57 & 1,27 \\
\hline 7 & MRAR 17-10-3-6 & 7,54 & 6,05 & 4,75 & 219,68 & 12,96 & 1,25 & 1,59 & 1,28 \\
\hline 8 & MRAR 28-15-21-7 & 7,69 & 6,24 & 4,86 & 237,42 & 12,48 & 1,24 & 1,59 & 1,29 \\
\hline 9 & MRAR 29-12-26-1 1 & $8,18 \mathrm{a}$ & $6,52 \mathrm{a}$ & 5,19 a & 278,38 a & $15,84 \mathrm{a}$ & 1,26 & 1,58 & 1,26 \\
\hline 10 & MRAR 29-12-27-8 & 7,37 & 6,27 & 5,03 a & 234,10 & 13,12 & $1,18 \mathrm{~b}$ & $1,47 \mathrm{~b}$ & $1,25 \mathrm{~b}$ \\
\hline 11 & MRAR 29-15-28-4 & 7,51 & 6,11 & 4,76 & 220,85 & 12,92 & 1,23 & 1,58 & 1,29 \\
\hline 12 & MRAR 29-15-32-12 & 7,89 a & $6,38 \mathrm{a}$ & 4,95 & $254,51 \mathrm{a}$ & 14,56 a & 1,24 & 1,59 & 1,29 \\
\hline 13 & MRAR 29-15-33-14 & $7,80 \mathrm{a}$ & 6,28 & 4,93 & 244,94 & 14,04 & 1,24 & 1,60 & 1,28 \\
\hline 14 & MRAR 29-15-33-5 & 7,89 a & 6,19 & 4,77 & 236,92 & 13,72 & 1,28 & 1,66 & 1,30 \\
\hline 15 & MRAR 29-15-33-7 & $8,24 \mathrm{a}$ & $6,47 \mathrm{a}$ & 5,07 a & 273,67 a & 15,28 a & 1,27 & 1,63 & 1,28 \\
\hline 16 & MRAR 29-15-36-4 & 8,49 a & 6,62 a & 5,23 a & 296,79 a & $16,76 \mathrm{a}$ & 1,28 & 1,63 & 1,27 \\
\hline 17 & MRAR 29-15-36-8 & $8,47 \mathrm{a}$ & $6,78 \mathrm{a}$ & 5,29 a & 304,87 a & $16,72 \mathrm{a}$ & 1,25 & 1,61 & 1,29 \\
\hline 18 & MRAR 29-15-30-10 & 8,29 a & 6,53 a & 5,09 a & 264,17 a & $16,00 \mathrm{a}$ & 1,36 & 1,60 & 1,29 \\
\hline 19 & MRAR 30-1-39-9 & 6,64 & 5,43 & 4,31 & 205,77 & $16,60 \mathrm{a}$ & 1,22 & $1,54 \mathrm{~b}$ & 1,26 \\
\hline 20 & Arjasari & 7,64 & 6,22 & 4,92 & 236,50 & 13,60 & 1,23 & 1,56 & 1,27 \\
\hline
\end{tabular}

Keterangan : 1) $\mathrm{PB}=$ Panjang Biji; TB = Tebal Biji; LB = Lebar Biji; DB = Dimensi Biji; B-100 = Bobot 100 Biji; $\mathrm{P} / \mathrm{T}=$ Rasio Panjang-Tebal Biji, P/L = Rasio Panjang-Tebal Biji, dan L/T = Rasio Lebar-Tebal Biji.

2) $\mathrm{a}=$ Berbeda nyata lebih besar dibandingkan varietas Arjasari pada taraf $5 \%$; $\mathrm{b}=$ Berbeda nyata lebih baik dibandingkan varietas Arjasari Arjasari pada taraf 5\%.

Analisis klaster bertujuan untuk mengelompokan obyek data yang memiliki kesamaan satu sama lain disatukan dalam kelompok yang sama dan tidak memiliki kesamaan dengan obyek data yang lain (Hosseini et al., 2010). Gambar 1 memperlihatkan hubungan ketidak-miripan di antara genotip-genotip mutan kedelai berdasarkan jarak euclidian. Sitepu et al. (2011) menyatakan bahwa jarak ketidak-miripan yang besar ditandai dengan koefisien euclidean $>1,00$, sedangkan pada koefisien euclidean $0,00 \leq 1,00$ menyatakan ketidakmiripan yang kecil. Variasi sempit dari genotip-genotip memiliki koefisien ketidakmiripan yang kecil, sebaliknya untuk variasi yang luas memiliki koefisien ketidakmiripan yang besar (Tairo et al., 2008).

Gambar 1 memperlihatkan dua klaster (A dan B) genotip mutan kedelai yang berbeda satu dengan lainnya; berjarak eucledian sebesar 1,53. Genotipgenotip mutan kedelai yang berada di dua klaster yang berbeda (A dan B) memiliki ketidak-miripan yang besar. Klaster genotip mutan kedelai A terdiri dari dua subklaster A1 dan A2 yang berjarak euclidian sebesar 0,952 . Genotip-genotip mutan kedelai dalam dua klaster tersebut memiliki ketidak-miripan yang kecil, atau memiliki kemiripan yang besar. Terdapat sepuluh genotip mutan yang kemiripan yang besar satu dengan lainnya; yaitu MRAR 14-11-17-5, MRAR 2915-36-4, MRAR 26-6-21-8, MRAR 29-15-36-8, MRAR 15-17-31-11, MRAR 29-12-26-11, MRAR 2915-33-7, MRAR 13-5-16-5, MRAR 29-15-30-10, dan MRAR 29-15-32-12. Genotip-genotip mutan kedelai tersebut memiliki memiliki karakter-karakter ukuran biji yang lebih besar dibandingkan dengan varietas Arjasari; kecuali MRAR 13-5-16-5 dan MRAR 29-1532-12. Genotip mutan kedelai MRAR 15-17-31-11 juga memiliki sifat lebih bulat dibandingkan varietas Arjasari (Tabel 2). 


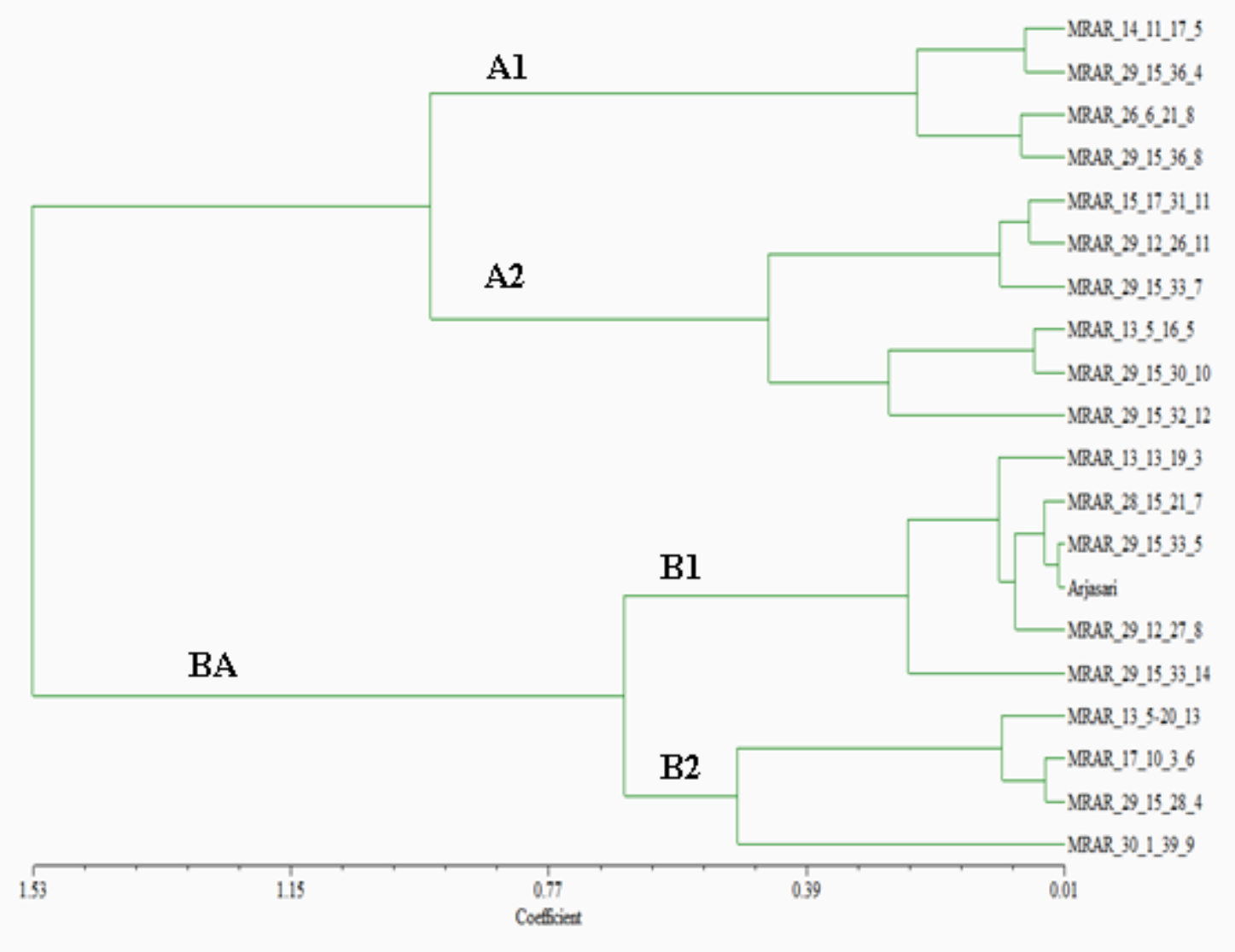

Gambar 1. Dendogram Hasil Analisis Klaster Karakter-karakter Ukuran dan Bentuk Biji dari Genotip-genotip mutan Kedelai Generasi M4

Klaster B terdiri dari subklaster B1 dan B2 yang masing-masing berjarak euclidian 0,663; dengan ketidak-miripan kecil. Genotip-genotip mutan kedelai pada kedua klaster tersebut dikategorikan memiliki kemiripan satu dengan lainnya. Salah satu genotip mutan kedelai tersebut adalah varietas Arjasari. Oleh karena itu, sembilan genotip muan kedelai yang terletak di klaster B1 dan B2 pada dasarnya memiliki kemiripan yang besar. Sepuluh genotip mutan kedelai tersebut pada dasarnya memiliki karakteristik ukuran biji dan bentuk biji yang tidak berbeda dengan varietas Arjasari; kecuali MRAR 29-12-27-8 untuk karakter bentuk biji (Tabel 2 ).

Dimensi biji secara bersama-sama dibangun oleh panjang biji, tebal biji, dan lebar biji, menjadikan karakter ukuran biji. Hubungan diantara karakterkarakter tersebut diperlihatkan pada Tabel 3. Karakter-karakter penyusun ukuran biji, yaitu panjang biji, tebal biji, lebar biji, dan dimensi biji, memiliki korelasi sesamanya yang sangat nyata; dengan nilai korelasi (r) berkisar 0,85-0,98. Menurut
Fehr (1987), adanya hubungan korelasi di antara dua karakter dapat disebabkan oleh pautan (Linkage) atau pleiotropi. Mengingat sejumlah peneliti (Salas et al., 2006; Che et al., 2013; Dargahi et al., 2015; dan Teng et al., 2017) melaporkan bahwa ukuran biji kedelai merupakan Quantitative Traits Loci (QTL), maka diduga korelasi tersebut yang sangat kuat tersebut mengindikasikan adanya pautan di antara gen-gen pengendali karakter-karakter ukuran biji. Kondisi pautan di antara gen-gen pengendali karakter ukuran biji kedelai telah dilaporkan oleh beberapa peneliti $(\mathrm{Hu}$ et al., 2013; Niu et al., 2013; Che et al., 2014; Dargahi et al., 2015).

Kondisi karakter bentuk biji tidak berbeda dengan karakter ukuran biji. Karakter bentuk biji yang tersusun oleh rasio panjang-tebal biji, rasio panjanglebar biji, dan rasio tebal-lebar biji juga memperlihatkan korelasi yang kuat (Tabel 3). Salas et al. (2006), Niu et al. (2013) dan Teng et al. (2017) melaporkan bahwa karakter bentuk biji kedelai besifat QTL. 
Tabel 3. Korelasi Penampilan Karakter-karakter Ukuran Biji pada Genotip-genotip Mutan Kedelai Generasi M $_{4}$

\begin{tabular}{|c|c|c|c|c|c|c|c|c|}
\hline & PB ${ }^{1)}$ & TB & LB & DB & B-100 & $\mathbf{P} / \mathbf{T}$ & $\mathbf{P} / \mathbf{L}$ & $\mathbf{T} / \mathbf{L}$ \\
\hline PB & & $0.91 * * 2)$ & $0.85 * *$ & 0.88 ** & $0.45 *$ & $0.48^{*}$ & 0.43 & 0.16 \\
\hline TB & $0.91 * *$ & & $0.98 * *$ & $0.93 * *$ & $0.50 *$ & 0.13 & 0.05 & -0.03 \\
\hline LB & $0.85 * *$ & $0.98 * *$ & & 0.92 ** & $0.54^{*}$ & 0.03 & -0.10 & -0.24 \\
\hline DB & $0.88 * *$ & $0.93 * *$ & $0.92 * *$ & & $0.72 * *$ & 0.14 & 0.09 & -0.14 \\
\hline B-100 & $0.45 *$ & $0.50 *$ & $0.54 *$ & $0.72 * *$ & & 0.08 & -0.11 & -0.30 \\
\hline $\mathbf{P} / \mathbf{T}$ & $0.48 *$ & 0.13 & 0.03 & 0.14 & 0.08 & & $0.75 * *$ & $0.47 *$ \\
\hline $\mathbf{P} / \mathbf{L}$ & 0.43 & 0.05 & -0.10 & 0.09 & -0.11 & $0.75 * *$ & & 0.68 *** \\
\hline $\mathrm{T} / \mathrm{L}$ & 0.16 & -0.03 & -0.24 & -0.14 & -0.30 & $0.47 *$ & $0.68 * *$ & \\
\hline
\end{tabular}

Keterangan : 1) $\mathrm{PB}=$ Panjang Biji; TB = Tebal Biji; LB = Lebar Biji; DB = Dimensi Biji; B-100 = Bobot 100 Biji; $\mathrm{P} / \mathrm{T}=$ Rasio Panjang-Tebal Biji, P/L = Rasio Panjang-Tebal Biji, dan L/T = Rasio Lebar-Tebal Biji.

2) $* *=$ Berbeda nyata pada taraf $1 \%$; = Berbeda nyata pada taraf $5 \%$.

Sehingga tidak berbeda dengan kondisi karakter ukuran biji, kuatnya korelasi di antara karakterkarakter bentuk biji diduga disebabkan oleh adanya pautan. Namun demikian, antar karakter-karakter ukuran biji dan karkater bentuk biji pada umumnya tidak memperlihatkan adanya hubungan korelasi (Tabel 3). Menurut Hu et al. (2013), karakter ukuran biji dan karakter bentuk biji kemungkinan dikendalikan oleh faktor genetik yang berbeda.

\section{Kesimpulan}

1. Variasi intrapopulasi karakter-karakter ukuran biji dan bentuk biji dari 19 genotip mutan kedelai generasi M4 pada umumnya dikategorikan sempit;

2. Delapan genotip mutan kedelai generasi $\mathbf{M}_{4}$, yaitu MRAR 14-11-17-5, MRAR 15-17-31-11, MRAR 26-6-2 1-8, MRAR 29-12-26-1 1, MRAR 29-15-337, MRAR 29-15-36-4, MRAR 29-15-36-8, dan MRAR 29-15-30-10, memiliki karakter-karakter ukuran biji yang lebih besar dibandingkan dengan varietas Arjasari. Genotip MRAR 15-17-31-11 dan MRAR 29-12-27-8 memiliki bentuk biji lebih bulat berbeda dengan varietas Arjasari;

3. Karakter-karakter ukuran biji dan bentuk biji masing-masing saling berkorelasi sangat kuat. Karakter-karakter ukuran biji tidak berkorelasi dengan karakter-karakter bentuk biji.

\section{Daftar Pustaka}

Acquuah, G. 2007. Principles of Plant Genetics and Breeding. Blackwell publishing. USA. 569 pp
Allard, R.W. 1961. Principles of Plant Breeding. John Wiley, New York.

Arsyad, D. M. 2000. Varietas unggul dan strategi pemuliaan kedelai di Indonesia, hal 39-42. Dalam: L. W. Gunawan, N. Sunarlim, T. Handayani, B. Soegiharto, W. Adil, B. Priyanto, dan Suwarno (Eds.). Penelitian dan pengembangan produksi kedelai di Indonesia. Pusat penelitian dan pengembangan tanaman pangan. Badan Penelitian dan Pengembangan Pertanian.

Chahal G.S., and S.S. Gosal. 2006. Principles and Procedures of Plant Breeding, Biotechnological and Conventional Approaches. Pangbaurne (UK): Alpha Science International Ltd.

Che, J.Y., J.J. Ding, C.Y. Liu, D.W. Xin, H.W. Jiang, G.H. Hu, and Q.S. Chen. 2014. Quantative trait loci of seed traits for soybean in multiple environments. Genetics and Molecular Research 13 (2): 4000-4012.

Crowder, L. V. 1986. Mutagenesis. Hal 322 - 356. Dalam Soetarso (Ed). Genetika Tumbuhan. Gadjah Mada University Press. Jogjakarta.

Fehr, W.R. 1987. Principles of Cultivar Development, volume I: Theory and Tehcnique. MacMillan Publishing. New York.

Dargahi, H., P. Tanya, and P. Srinives. (2015). Detection of quantitative trait loci for seed size traits in soybean (Glycine max L.). Kasetsart J. (Nat. Sci.) 49: $832-843$

Hanafiah, Diana Sofia. Trikoesoemaningtyas, Sudirman Yahya dan Desta Wirnas. 2011. Penggunaan mikro irradiasi sinar gamma 
untuk meningkatkan keragaman genetik pada varietas kedelai Argomulyo (Glycine max L Merr). Jurnal Natur Indonesia. https://blast.ncbi.nlm.nih.gov/Blast.cgi

Hosseini, S. M. S., A. Maleki, and M. R. Gholamian. 2010. Cluster analysis using data mining approach to develop CRM methodology to asses the customer loyalty. Expert System with Applications (37) 5259-5264

Hu, Z., H. Zhang, G. Kan, D. Ma, D. Zhang, G. Shi, D. Hong, G. Zhang, D. Yu. 2013. Determination of the genetic architecture of seed size and shape via linkage and association analysis in soybean (Glycine max L. Merr.). Genetica (2013) 141:247-254.

Knight, R. 1979.Practical in Statistics and Quantitative Genetic.In R. Knight, (ed). A course manual in plant breeding, p. 213-225

Krisdiana, R. 2004. Preferensi industri tahu dan tempe dalam menggunakan bahan baku kedelai di Jawa Timur. hlm. 540-548. Dalam A.K. Makarim, Marwoto, M.M. Adie, A.A. Rahmianna, Heriyanto, dan I.K. Tastra (Ed.). Kinerja Penelitian Mendukung Agribisnis Kacang-kacangan dan Umbi-umbian. Pusat Penelitian dan Pengembangan Tanaman Pangan, Bogor.

Krisnawati, A. 2017. Kedelai sebagai Sumber Pangan Fungsional. Iptek Tanaman Pangan Vol. 12 No. 12017.

Liang H, S. Wang, Y. Yu, T. Wang, P. Gong, X. Fang, X. Liu, S. Zhao, M. Zhang, W. Li. (2008) Mapping quantitative trait loci for six seed shape traits in soybean. Henan Agric Sci 45:54-60

Niu, Y., Y. Xu, X. F. Liu, S. X.Yang, S. P. Wei, F. T. Xie, Y. M. Zhang. 2013. Association mapping for seed size and shape traits in soybean cultivars. Mol Breeding 31:785794.
Qosim, W.A., A. Karuniawan, B. Marwoto, D.S. Badriah. 2000. Stabilitas parameter genetik mutan-mutan krisan generasi VM3. Laporan Hasil Penelitian Lembaga Penelitian Universitas Padjajaran. Jatinangor

Salas, P., J.C. Oyarzo-Llaipen, D. Wang, K. Chase and L. Mansur. 2006. Genetic mapping of seed shape in three populations of recombinant inbred lines of soybean (Glycine max L. Merr.). Theor. Appl. Genet. 113: 1459-1466.

Sihombing Y.B.L., D.S. Hanafiah, Y. Husni. 2016. Seleksi individu M3 berdasarkan karakter umur genjah dan produksi tinggi pada tanaman kedelai (Glycine $\max$ L. Merrill). Jurnal Agroteknologi, 4 (4): 2272-2283

Sitepu, R., Irmeiyana, dan B. Gultom. 2011. Analisis cluster terhadap tingkat pencemeran udara pada sektor industry di sumatera selatan. Sains 14(3): 11-17

Tairo, F., E. Mneney, and A. Kullaya. 2008. Morphological and agronomical characterization of aweet potato (Ipomoea batatas (L.) Lam.) germplasm collection from Tanzania. African Journal of Plant Science 2(8): 77-85

Teng, W. L., M. N. Sui, W. Li, D. P. Wu, X. Zhao, H. Y. Li, Y. P. Han and W. B. Li. 2017. Identification of quantitative trait loci underlying seed shape in soybean across multiple environments. The Journal of Agricultural Science https://doi.org/10.1017/SO0218596170008 $\underline{\mathrm{QX}}$

Xie, F.T, Y. Niu, J. Zhang, S.H. Bu, H.Z. Zhang, Q.C. Geng, J.Y. Feng, and Y.M. Zhang. (2014). Fine mapping of quantitative trait loci for seed size traits in soybean. Molecular Breeding 34, 2165-2178. 